\title{
Autotetraploid plant regeneration by indirect somatic embryogenesis from leaf mesophyll protoplasts of diploid Gentiana decumbens L.f.
}

\author{
Karolina Tomiczak • Anna Mikuła • Elwira Sliwinska • \\ Jan J. Rybczyński
}

Received: 20 March 2014 / Accepted: 21 January 2015 / Published online: 11 March 2015 / Editor: Jude Grosser

(C) The Society for In Vitro Biology 2015

\begin{abstract}
Somaclonal variation, often manifested as the increased ploidy of plants observed following in vitro culture, can be advantageous in ornamental species or those used for secondary metabolite production. Polyploidy occurs especially when plantlets are produced by protoplast and callus cultures. Plants were regenerated from green leaf mesophyll protoplasts of diploid Gentiana decumbens L.f. through somatic embryogenesis. A yield of more than $9 \times 10^{5}$ protoplasts per gram of fresh weight was achieved by incubating fully expanded young leaves in an enzyme mixture containing $1.0 \%$ $(w / v)$ cellulase and $0.5 \%(w / v)$ macerozyme. Protoplasts, cultured in agarose beads using a modified Murashige and Skoog medium, divided and formed microcalli, with the highest plating efficiency obtained on medium containing $2.0 \mathrm{mg} \mathrm{l}^{-1} 1$ naphthaleneacetic acid and $0.1 \mathrm{mg}^{-1}$ thidiazuron. Callus proliferation was also promoted by including thidiazuron in agarsolidified medium, while somatic embryogenesis was induced from microcalli on medium supplemented with $1.0 \mathrm{mg} \mathrm{l}^{-1}$ kinetin, $0.5 \mathrm{mg} \mathrm{l}^{-1}$ gibberellic acid, and $80 \mathrm{mg} \mathrm{l}^{-1}$ adenine sulfate. Flow cytometric analysis and chromosome counting revealed that all regenerants were tetraploid.
\end{abstract}

Keywords Protoplast culture $\cdot$ Somaclonal variation . Gentian $\cdot$ Flow cytometry $\cdot$ Chromosome number

\footnotetext{
K. Tomiczak $(\bowtie) \cdot$ A. Mikuła $\cdot$ J. J. Rybczyński Department of Experimental Plant Biology, Polish Academy of Sciences Botanical Garden-Center for Biological Diversity in Powsin, Prawdziwka 2, 02-973 Warsaw, Poland e-mail: ktomiczak@obpan.pl

\section{E. Sliwinska}

Department of Plant Genetics, Physiology and Biotechnology, Laboratory of Molecular Biology and Cytometry, University of Technology and Life Sciences, Kaliskiego Ave. 7 , 85-789 Bydgoszcz, Poland
}

\section{Introduction}

Gentiana decumbens L.f., is one of about 360 Gentiana species, well known for their pharmacological properties and decorative flowers. It is a diploid $(2 n=2 x=26)$ perennial herb growing on grassland slopes and dry steppes of Kazakhstan, Mongolia, Russia, and China (Ho and Pringle 1995). According to the classification of Ho and Liu (1990), this species, together with Gentiana crassicaulis Duthie ex Burk., Gentiana cruciata L., Gentiana kurroo Royle, Gentiana macrophylla Pall., Gentiana straminea Maxim., and Gentiana tibetica King, belongs taxonomically to the section Cruciata, comprising diploid and tetraploid species with 26 or 52 chromosomes, respectively. G. decumbens, like other gentians, is a source of bitter secoiridoid glucosides and flavonoids (Dungerdorj et al. 2006), and it possesses high antioxidant potency both in vitro and ex vivo (Myagmar and Aniya 2000). G. decumbens is used extensively in traditional Mongolian medicine for the treatment of liver diseases (Dungerdorj et al. 2006; Kletter et al. 2008), while in Pakistan, a tincture of this plant is prepared to treat stomach disorders (Qureshi et al. 2007). Due to its blue flowers and ease of cultivation, $G$. decumbens is also planted in rock and alpine gardens (Köhlein 1991).

Modern biotechnology offers important tools for mass propagation and genetic improvement of medicinal and ornamental plants. In the genus Gentiana, protocols for efficient in vitro multiplication have been described for at least 18 species, initiated from a wide range of explant types (Rybczyński et al. 2015). The high morphogenic potential of most of these species facilitates the in vitro genetic manipulations of these plants, carried out mainly via Agrobacteriummediated transformation (Rybczyński et al. 2015). Protoplasts could also be used for plant genetic improvement by somatic hybridization, direct genetic transformation, and somaclonal 
variation. These approaches could be implemented to produce novel Gentiana genotypes and hybrids with desirable secondary metabolite content or visually attractive phenotypes (Nishihara et al. 2003). However, the use of protoplast technology for these reasons requires the development of effective protocols for plant regeneration from cultured protoplasts.

To date, four Gentiana species and one interspecific hybrid have been regenerated from protoplasts. Takahata and Jomori (1989) first reported low-frequency shoot organogenesis from green leaf mesophyll protoplasts of Gentiana scabra Bunge. Plant regeneration from mesophyll protoplasts of Gentiana triflora Pall. and Gentiana triflora $\times$ Gentiana scabra via organogenesis have also been reported (Nakano et al. 1995). In contrast, use of somatic embryogenesis as the route for plant regeneration from protoplasts has been restricted so far to protoplasts derived from undifferentiated plant material such as embryogenic callus of G. crassicaulis, induced from hypocotyl explants (Meng et al. 1996), or from highly embryogenic cell suspensions of G. kurroo (Fiuk and Rybczyński 2007).

The aim of this work was to develop a protocol for efficient plant regeneration from protoplasts of differentiated green leaf mesophyll cells of $G$. decumbens. The regenerants were evaluated using both direct and indirect methods to estimate ploidy.

\section{Materials and Methods}

Plant Material. Seeds of $G$. decumbens were obtained from the Berlin-Dahlem Botanical Garden and Botanical Museum in Berlin, Germany. The seeds were surface sterilized for $30 \mathrm{~s}$ in $70 \%(\mathrm{v} / \mathrm{v})$ ethanol, followed by $15 \mathrm{~min}$ in $1 \%(v / v)$ sodium hypochlorite solution, followed by three rinses in sterile water. Seeds were placed on half-strength Murashige and Skoog (MS) medium (Murashige and Skoog 1962) supplemented with $0.5 \mathrm{mg} \mathrm{l}^{-1}$ gibberellic acid $\left(\mathrm{GA}_{3}\right), 10 \mathrm{~g} \mathrm{l}^{-1}$ sucrose, and $7 \mathrm{~g} \mathrm{l}^{-1}$ agar. The $\mathrm{pH}$ of the medium was adjusted to 5.8 with $0.1 \mathrm{M} \mathrm{NaOH}$ or $0.1 \mathrm{M} \mathrm{HCl}$ before autoclaving at $121^{\circ} \mathrm{C}$ for $18 \mathrm{~min}$. After $3 \mathrm{wk}$, seedlings were transferred to 450 -ml glass jars containing $80 \mathrm{ml}$ of half-strength MS medium with $15 \mathrm{~g} \mathrm{l}^{-1}$ sucrose and $8 \mathrm{~g} \mathrm{l}^{-1}$ agar, and maintained in a growth chamber at $21 \pm 1^{\circ} \mathrm{C}$ with 16 -h illumination of $150 \mu \mathrm{M} \mathrm{m}^{-2} \mathrm{~s}^{-1}$ provided by daylight fluorescent tubes. The plantlets were subcultured to new medium every 3 4 mo.

Protoplast Isolation. Fully expanded, young leaves were harvested from in vitro-grown $G$. decumbens plants. After removal of the lower epidermis, $1 \mathrm{~g}$ of leaf material was submerged in $10 \mathrm{ml}$ of cell and protoplast wash solution (CPW; Frearson et al. 1973) supplemented with $0.33 \mathrm{M}$ mannitol (pH 5.8) for $30 \mathrm{~min}$ of pre-plasmolysis. Leaf tissues were then incubated in filter-sterilized enzyme solution for $3-4 \mathrm{~h}$ in the dark at $26^{\circ} \mathrm{C}$ on a rotary shaker $(50 \mathrm{rpm})$. The enzyme mixture consisted of $1.0 \%$ $(w / v)$ Cellulase Onozuka R-10 and 0.5\% (w/v) Macerozyme R-10 (both from Yakult Honsha Co., Ltd., Tokyo, Japan), dissolved in CPW solution with $0.5 \mathrm{M}$ mannitol and $5 \mathrm{mM}$ 2-( $\mathrm{N}$-morpholino)ethanesulfonic acid (MES), pH 5.8. Released protoplasts were filtered through a $45-\mu \mathrm{m}$ nylon sieve and collected by centrifugation at $180 \mathrm{rpm}$ for $10 \mathrm{~min}$. The pellet was resuspended in CPW solution containing $0.5 \mathrm{M}$ mannitol and centrifuged at $180 \mathrm{rpm}$ for $10 \mathrm{~min}$. This centrifugation and resuspension procedure was performed three times.

Microscopic Evaluation of Protoplasts. For observation of protoplasts, an epifluorescence microscope (Vanox AHBT3; Olympus, Tokyo, Japan) was used. The yield of freshly isolated protoplasts was determined using a Bürker counting chamber and expressed as the number of protoplasts obtained from $1 \mathrm{~g}$ of fresh weight of leaves. Protoplast diameters were measured using analySIS ${ }^{\circledR}$ FIVE software (Olympus). Viability was estimated by staining protoplasts with $0.01 \%(w / v)$ fluorescein diacetate (FDA) solution (Larkin 1976). The mean yield, diameter, and viability of protoplasts were calculated on the basis of data from 6 independent isolations, and 10 microscopic fields of view per isolation.

Protoplast Culture. Purified protoplasts were suspended at a density of $1.0 \times 10^{5}$ cells per milliliter in protoplast culture medium (PCM; Table 1) supplemented with $0.5 \mathrm{M}$ mannitol and $0.8 \%(w / v)$ Sea Plaque ${ }^{\circledR}$ Agarose (Cambrex Bio Science Rockland Inc., Rockland, ME). Twelve to 14 agarose beads each of $100 \mu \mathrm{l}$ in volume and about $7 \mathrm{~mm}$ in diameter were formed on each 50-mm Petri dish. After setting, the beads were submerged in $5.0 \mathrm{ml}$ of PCM liquid medium.

Protoplast cultures were incubated at either 21 or $26^{\circ} \mathrm{C}$ in the dark. During the first week of culture, cell wall regeneration was monitored by staining protoplasts with $0.001 \%(w / v)$ calcofluor (Fluorescent Brightener 28, Sigma-Aldrich, St. Louis, MO) solution. On the seventh day of culture, plating efficiency was determined. Dividing cells were counted using an IMT-2 inverted microscope (Olympus) from 6 independent agarose bead cultures, with 10 fields of view per culture. Plating efficiency was expressed as the number of cells that divided at least once per total number of plated protoplasts, multiplied by 100 .

To avoid browning of the cultures, $2.5 \mathrm{ml}$ of the liquid medium was replaced with the same amount of the same 
Table 1. Media used for the culture of Gentiana protoplasts, callus proliferation, and plant regeneration

\begin{tabular}{|c|c|}
\hline $\begin{array}{l}\text { Medium } \\
\text { code }\end{array}$ & Medium components \\
\hline PCM1 & MS salts (without $\mathrm{NH}_{4} \mathrm{NO}_{3}$ ) and vitamins, $30 \mathrm{~g} \mathrm{l}^{-1}$ glucose, $3.0 \mathrm{~g}^{-1}$ glutamine, $2.0 \mathrm{mg}^{-1} \mathrm{NAA}, 0.1 \mathrm{mg} \mathrm{l}^{-1} \mathrm{TDZ}^{\mathrm{a}}$ \\
\hline PCM2 & MS salts (without $\mathrm{NH}_{4} \mathrm{NO}_{3}$ ) and vitamins, $30 \mathrm{~g} \mathrm{l}^{-1}$ glucose, $3.0 \mathrm{~g}^{-1}$ glutamine, $2.0 \mathrm{mg}^{-1} \mathrm{NAA}, 1.0 \mathrm{mg} \mathrm{l}^{-1} \mathrm{BAP}^{\mathrm{a}}$ \\
\hline CPM1 & MS salts and vitamins, $30 \mathrm{~g}^{-1}$ sucrose, $2.0 \mathrm{mg}^{-1} \mathrm{NAA}, 0.2 \mathrm{mg}^{-1} \mathrm{TDZ}$ \\
\hline CPM2 & MS salts and vitamins, $30 \mathrm{~g} \mathrm{l}^{-1}$ sucrose, $2.0 \mathrm{mg} \mathrm{l}^{-1} \mathrm{NAA}, 1.0 \mathrm{mg}^{-1} \mathrm{BAP}$ \\
\hline СРM3 & 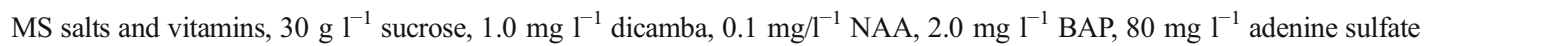 \\
\hline CPM4 & MS salts and vitamins, $30 \mathrm{~g} \mathrm{l}^{-1}$ sucrose, $0.5 \mathrm{mg} \mathrm{l}^{-1} 2,4-\mathrm{D}, 1.0 \mathrm{mg} \mathrm{l}^{-1}$ kinetin \\
\hline PRM1 & MS salts and vitamins, $30 \mathrm{~g} \mathrm{l}^{-1}$ sucrose, $20 \mathrm{ml} \mathrm{l}^{-1}$ coconut water, $0.1 \mathrm{mg} \mathrm{l}^{-1} \mathrm{NAA}, 8.0 \mathrm{mg} \mathrm{l}^{-1} \mathrm{TDZ}$ \\
\hline PRM2 & MS salts and vitamins, $30 \mathrm{~g} \mathrm{l}^{-1}$ sucrose, $20 \mathrm{ml} \mathrm{l}^{-1}$ coconut water, $0.1 \mathrm{mg} \mathrm{l}^{-1} \mathrm{NAA}, 6.0 \mathrm{mg} \mathrm{l}^{-1} \mathrm{BAP}$ \\
\hline PRM3 & MS salts and vitamins, $30 \mathrm{~g} \mathrm{l}^{-1}$ sucrose, $20 \mathrm{ml} \mathrm{l}^{-1}$ coconut water, $1.0 \mathrm{mg} \mathrm{l}^{-1}$ kinetin, $0.5 \mathrm{mg} \mathrm{l}^{-1} \mathrm{GA}_{3}, 80 \mathrm{mg} \mathrm{l}^{-1}$ adenine sulfate \\
\hline PRM4 & MS salts and vitamins, $30 \mathrm{~g} \mathrm{l}^{-1}$ sucrose, $20 \mathrm{ml} \mathrm{l}^{-1}$ coconut water, $1.0 \mathrm{mg} \mathrm{l}^{-1} \mathrm{NAA}, 2.0 \mathrm{mg} \mathrm{l}^{-1} \mathrm{BAP}, 3.0 \mathrm{mg} \mathrm{l}^{-1} \mathrm{zeatin} 1.0 \mathrm{mg}^{-1} \mathrm{GA}_{3}$ \\
\hline
\end{tabular}

$P C M$ protoplast culture medium, $C P M$ callus proliferation medium, $P R M$ plant regeneration medium

${ }^{a}$ PCM media were supplemented with different concentrations of mannitol $(0.5,0.33,0.17$, or $0.0 \mathrm{M})$, as described in the "Materials and Methods"

fresh medium every week. To stimulate further cell division and colony formation, the osmotic pressure of the media was gradually reduced starting from the fifth week of the culture. This was accomplished by replacing $2.5 \mathrm{ml}$ of the current liquid PCM medium with the same amount of medium supplemented with $0.33 \mathrm{M}$ mannitol during the fifth and sixth week of culture, $0.17 \mathrm{M}$ mannitol in the seventh and eighth weeks, and no mannitol in subsequent weeks.

Callus Culture and Plant Regeneration. When protoplastderived microcalli reached about $1-2 \mathrm{~mm}$ in diameter, agarose beads were transferred to $90-\mathrm{mm}$ Petri dishes with agar-solidified callus proliferation medium (CPM; Table 1) and cultured in the dark at $26^{\circ} \mathrm{C}$. The rate of callus proliferation was estimated $4 \mathrm{wk}$ after transfer to CPM by the comparison of the surface of formed tissue with the surface of the agarose bead. Depending on the proliferation rate, callus lines were placed on agarsolidified plant regeneration medium (PRM) after 4 to 8 wk (Table 1) and cultured under growth chamber conditions $\left(21^{\circ} \mathrm{C}, 16 / 8 \mathrm{~h}\right.$ photoperiod, $150 \mu \mathrm{M} \mathrm{m}^{-2} \mathrm{~s}^{-1}$ light intensity) to obtain plant regeneration. If no regeneration was observed after $8 \mathrm{wk}$, callus was transferred onto PRM3 or PRM4 medium for an additional 4 wk. Mature somatic embryos were transferred to glass jars with agarsolidified half-strength MS medium supplemented with $15 \mathrm{~g} \mathrm{l}^{-1}$ sucrose for germination. Regenerants were subsequently grown on growth-regulator-free MS medium containing $30 \mathrm{~g} \mathrm{l}^{-1}$ sucrose.

Flow Cytometry. Nuclear DNA content was determined for 15 seed-derived plants from which protoplasts were obtained and for 21 independently regenerated, randomly chosen plants. Pisum sativum L. 'Set' $(9.11 \mathrm{pg} / 2 \mathrm{C}$;
Sliwinska et al. 2005) served as an internal standard. Young leaves of $G$. decumbens and P. sativum were chopped simultaneously using a sharp razor blade in a Petri dish with $1.0 \mathrm{ml}$ of nuclei-isolation buffer $(0.1 \mathrm{M}$ Tris, $2.5 \mathrm{mM} \mathrm{MgCl}{ }_{2} \times 6 \mathrm{H}_{2} \mathrm{O}, 85 \mathrm{mM} \mathrm{NaCl}, 0.1 \%$ Triton $\mathrm{X}-100 ; \mathrm{pH}$ 7.0), supplemented with $50 \mu \mathrm{g} \mathrm{ml}^{-1}$ propidium iodide (PI) and $50 \mu \mathrm{g} \mathrm{ml}^{-1}$ RNase A. After chopping, the suspension was passed through a $50-\mu \mathrm{m}$ mesh nylon filter. For each sample, at least 7000 nuclei were analyzed using a Partec CCA (Münster, Germany) flow cytometer, equipped with an argon laser. Histograms were analyzed using the DPAC V.2.2 program (Partec GmbH, Münster, Germany). The nuclear DNA content was calculated using the linear relationship between the ratio of the $\mathrm{G}_{0} / \mathrm{G}_{1}$ peak positions of Gentiana and Pisum on the histogram of fluorescence intensity.

Chromosome Number Evaluation. For chromosome counts, roots collected from in vitro-grown regenerants and control plants were pretreated with $2 \mathrm{mM} 8$-hydroxyquinoline at $21^{\circ} \mathrm{C}$ for $2 \mathrm{~h}$ and then at $4{ }^{\circ} \mathrm{C}$ for $2 \mathrm{~h}$. After fixation in ethanol-acetic acid $(3: 1, v / v)$, roots were stored at $-20^{\circ} \mathrm{C}$ for at least $24 \mathrm{~h}$. Root tips were hydrolyzed in $5 \mathrm{M} \mathrm{HCl}$ for $50 \mathrm{~min}$ at $21^{\circ} \mathrm{C}$, stained in Schiff's reagent (SigmaAldrich) for $2 \mathrm{~h}$ in the dark, rinsed three times with potassium metabisulfite solution $\left(225 \mathrm{mM} \mathrm{K}_{2} \mathrm{~S}_{2} \mathrm{O}_{5}, 5 \mathrm{mM}\right.$ $\mathrm{HCl})$, squashed in a droplet of $45 \%(v / v)$ acetic acid on a microscope slide, and observed using a Vanox AHBT3 microscope under $\times 1000$ magnification. The chromosomes were counted using analySIS ${ }^{\circledR}$ FIVE software. At least 10 well-spread metaphase plates were analyzed for each plant.

Size and Frequency of Stomata. For stomatal measurements, the youngest pair of fully expanded leaves from 
in vitro-grown plants was used. A fragment of the lower epidermis from the middle portion of the leaf was removed and observed using a Vanox AHBT3 microscope. To determine the guard cell length and stomatal width, all stomata from 10 randomly selected fields of view per each leaf were measured using analySIS ${ }^{\circledR}$ FIVE software. Similarly, all stomata from 10 randomly selected leaf areas per leaf were counted. The stomatal frequency was expressed as a number of stomata per square millimeter of the leaf blade area.

Statistical Analysis. Each in vitro culture experiment consisted of three replicates. Each replicate comprised three Petri dishes for each combination of culture conditions. One-way analysis of variance (ANOVA) was performed using Statistica 6.0 software (StatSoft Polska Sp. z o.o., Krakow, Poland). Means were compared using Tukey's honestly significant difference (HSD) test, at the 0.05 level of significance.

\section{Results and Discussion}

Protoplast Isolation and Culture. The development of an efficient protoplast-to-plant system for a species of interest is a prerequisite for further research on its genetic manipulation through somatic hybridization or direct genetic transformation. Although high morphogenic potential has been demonstrated for many Gentiana species, expressed either as organogenic (Hosokawa et al. 1996; Momčilović et al. 1997) or embryogenic regeneration from various explant types (Mikuła and Rybczyński 2001; Fiuk and Rybczyński 2008b; Cai et al. 2009), the regeneration of plants from protoplasts has been limited to only a few species and hybrids (Takahata and Jomori 1989; Nakano et al. 1995; Meng et al. 1996; Fiuk and Rybczyński 2007). We could find no previous reports describing tissue culture of $G$. decumbens; thus, in designing the experiments, reports concerning protoplast culture of G. scabra, G. triflora, their hybrids, and especially of closely related G. crassicaulis and G. kurroo were taken into consideration. The enzyme mixture and protoplast isolation protocols described by other researchers working with Gentianaceae (Kunitake et al. 1995; Nakano et al. 1995) resulted in the release of $9.31 \pm 1.30 \times 10^{5}$ protoplasts per gram fresh leaf tissue of G. decumbens (Fig. 1a). The mean diameter of protoplasts was $24.35 \pm 4.94 \mu \mathrm{m}$ and their viability $84.60 \pm 4.08 \%$. Results achieved for $G$. decumbens were similar to those obtained for other gentian species (Nakano et al. 1995; Meng et al. 1996).

Protoplast culture using agarose beads surrounded by a liquid medium (Fig. 1b) was also used successfully by O'Brien and Lindsay (1993) for protoplasts of Eustoma grandiflorum Griseb., and its greater efficiency in the induction of cell division in G. kurroo compared to liquid and agarose thin-layer cultures was demonstrated by Fiuk and Rybczyński (2007). In agarose droplets, $G$. decumbens mesophyll protoplasts regenerated new cell walls within the first $48 \mathrm{~h}$ of culture (Fig. 1c) and underwent their first division 3-5 d after isolation (Fig. 1d). The second round of divisions started after about 5-7 d of culture.

The extent of cell division depends, among other things, on the media used for protoplast culture and on the physical conditions of incubation (Davey et al. 2005). In the present study, a comparison was made of the influence of the two cytokinins added to the protoplast culture medium, i.e., benzylaminopurine (BAP) and thidiazuron (TDZ), on plating efficiency. TDZ at a concentration of $0.1 \mathrm{mg} \mathrm{l}^{-1}$ stimulated cell division in cultures of mesophyll protoplasts of G. triflora and G. triflora $\times$ G. scabra more than BAP (Nakano et al. 1995). Similarly, for G. decumbens, a greater percentage of cell divisions was obtained on PCM1 medium, which contained TDZ (Table 2). Also, a temperature of $26^{\circ} \mathrm{C}$ gave almost twice the plating efficiency obtained at $21^{\circ} \mathrm{C}$. However, in spite of differences in rate, cell division continued and multicellular aggregates were obtained within 5-9 wk under all culture conditions tested (Fig. 1e). Visible protoplastderived microcalli formed after 10-12 wk.

Callus Culture and Plant Regeneration. Callus formation was observed after transfer of microcalluscontaining agarose beads onto CPM medium (Fig. 1f). Tissue proliferation was far more extensive when protoplasts had been cultured on TDZ-containing medium (PCM1) than on BAP-containing medium (PCM2) (Table 3). Similarly, the largest amount of callus formation was obtained on CPM1 medium, containing $2 \mathrm{mg}^{-1}$ 1-naphthaleneacetic acid (NAA) and $0.2 \mathrm{mg}^{-1} \mathrm{TDZ}$. However, another medium effective for callus proliferation was CPM4, containing 2,4-dichlorophenoxyacetic acid (2,4-D) and kinetin (Table 3). This medium was used previously for induction of callus on gentian seedling explants (Mikuła and Rybczyński 2001; Mikuła et al. 2002), for the initiation and culture of G. kurroo embryogenic cell suspensions (Fiuk and Rybczyński 2008a), and for culture of cell suspension-derived protoplasts (Fiuk and Rybczyński 2007). Tissues proliferating on CPM1 and CPM2 media were creamy colored and well hydrated while granular and yellowish calli formed on CPM3 and CPM4 media. The induction of somatic embryogenesis and the development of the first somatic embryos occurred after 6 wk of culture on CPM3 medium (Fig. 1 $g$ ).

Studies that have described plant regeneration from gentian mesophyll protoplasts indicate that the induction of morphogenesis is probably an intrinsic bottleneck in 
the process (Jomori et al. 1995; Takahata et al. 1995). Only Nakano et al. (1995) obtained a high frequency of shoot organogenesis (up to $28.6 \%$ ) for some genotypes of G. triflora and G. triflora $\times$ G. scabra, using high concentrations of TDZ $\left(5-10 \mathrm{mg}^{-1}\right)$ in combination with
$0.1 \mathrm{mg} \mathrm{l}^{-1} \mathrm{NAA}$ in the regeneration medium. As emphasized by Takahata et al. (1995), TDZ was expected to be exploited for tissue and protoplast culture of a wide range of Gentiana species. However, in the present experiments, after transferring protoplast-derived calli of $G$. decumbens
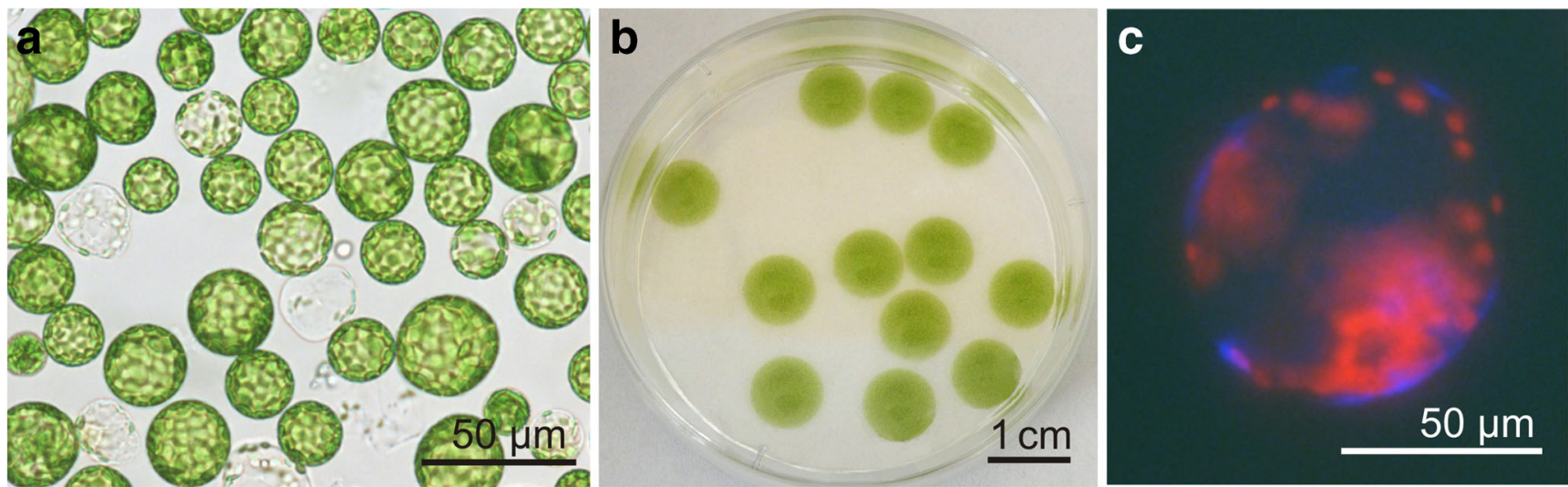

d

e

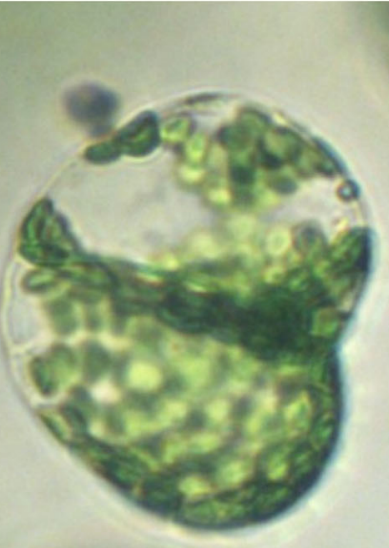

$50 \mu \mathrm{m}$
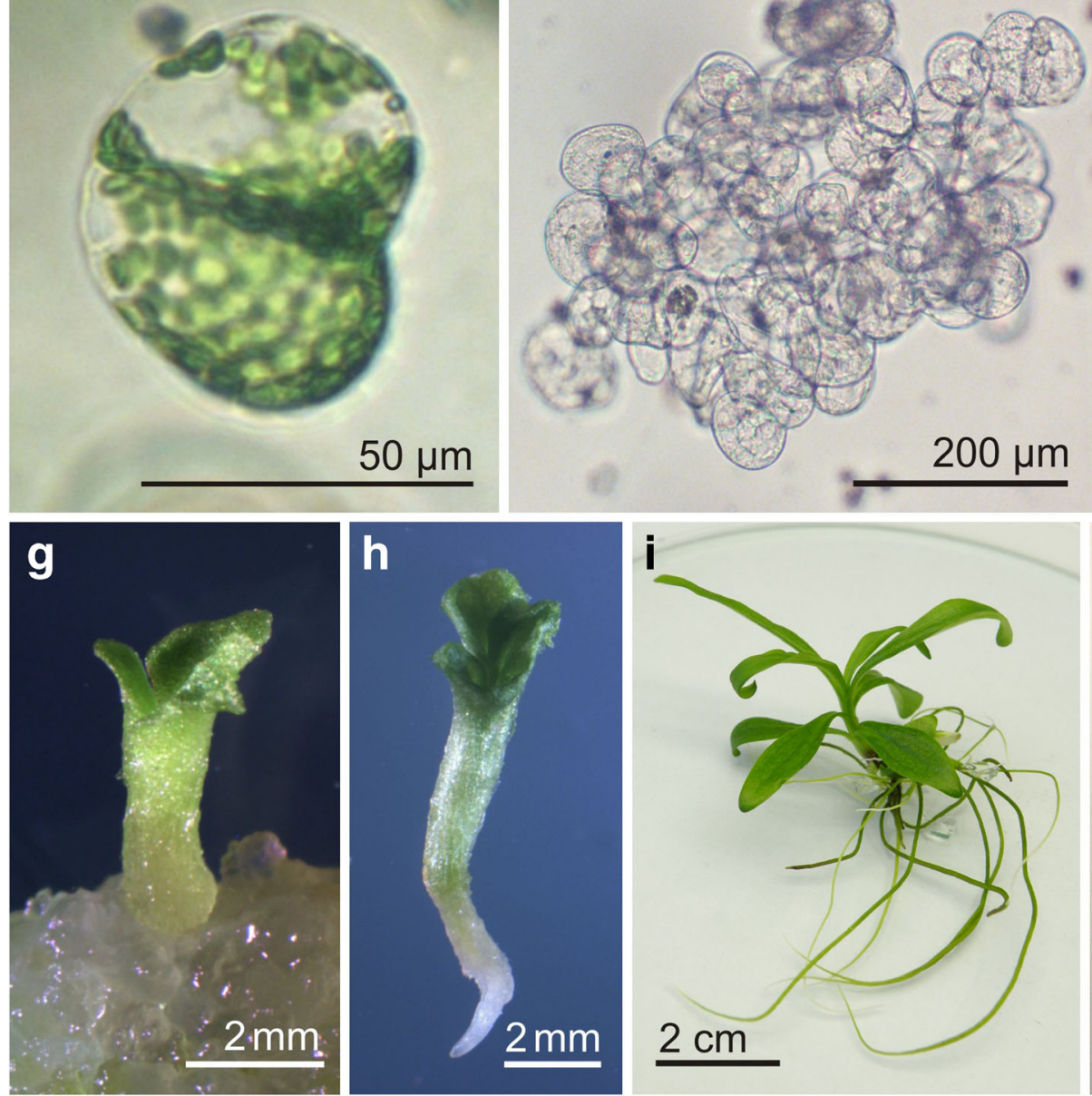

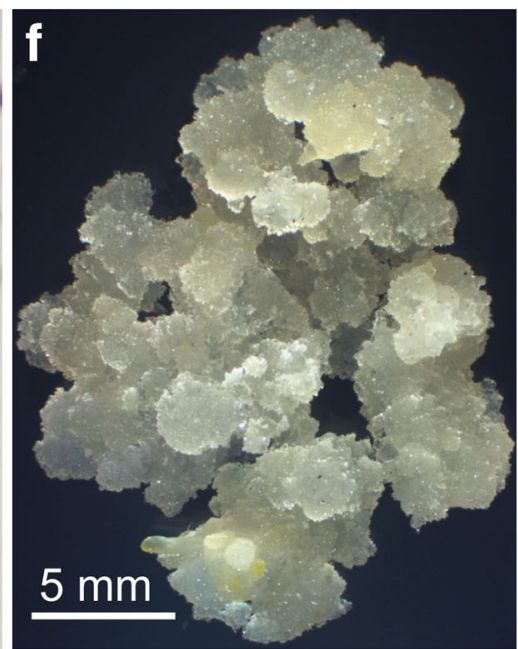

j

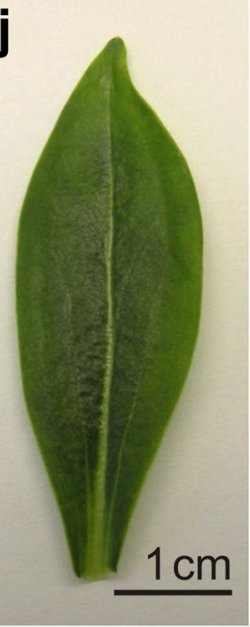

$\mathbf{K}$

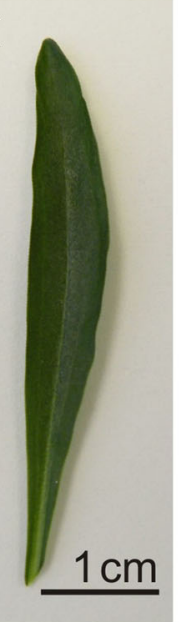

Figure 1. Regeneration of plants from protoplasts of Gentiana decumbens: (a) freshly isolated green leaf mesophyll protoplasts, $(b)$ protoplasts in agarose bead culture, $(c)$ regeneration of cell walls demonstrated by calcofluor staining, $(d)$ daughter cells formed after the first division of a protoplast-derived cell, $(e)$ multicellular aggregate obtained after $7 \mathrm{wk}$ of protoplast culture, $(f)$ callus proliferating on CPM4 medium, $(g)$ regenerating somatic embryo at the cotyledonary stage, $(h)$ mature somatic embryo before conversion into plantlet, $(i)$ protoplast-derived plant, $(j, k)$ leaf morphology of a protoplast-derived regenerant $(j)$, and a seed-derived parent plant $(k)$. 
Table 2. Percentages of dividing leaf mesophyll protoplast-derived cells of $G$. decumbens after $7 \mathrm{~d}$ of culture on two different media at two different temperatures

\begin{tabular}{lll}
\hline $\begin{array}{l}\text { Protoplast } \\
\text { culture medium }\end{array}$ & $\begin{array}{l}\text { Temperature of culture } \\
\text { incubation }\left({ }^{\circ} \mathrm{C}\right)\end{array}$ & $\begin{array}{l}\text { Percentage of dividing } \\
\text { cells }(\text { mean } \pm \text { SD) }\end{array}$ \\
\hline PCM1 & 21 & $3.11 \pm 0.60 \mathrm{~b}$ \\
& 26 & $6.07 \pm 2.03 \mathrm{a}$ \\
PCM2 & 21 & $2.15 \pm 0.50 \mathrm{~b}$ \\
& 26 & $4.11 \pm 0.58 \mathrm{ab}$
\end{tabular}

Values followed by the same letter are not significantly different at $P<0.05$ (HSD test)

onto plant regeneration media, no shoots regenerated on PRM1 medium, which contained $0.1 \mathrm{mg}^{-1} \mathrm{NAA}$ and $8 \mathrm{mg} \mathrm{l}^{-1}$ TDZ (Table 4). In contrast, the use of PRM3 medium, which ensured induction of somatic embryogenesis from callus and cell suspensions of Gentiana pannonica, G. cruciata, G. tibetica (Mikuła and Rybczyński 2001; Mikuła et al. 2002), and G. kurroo (Fiuk and Rybczyński 2008a) and from protoplasts of G. kurroo cell suspensions (Fiuk and Rybczyński 2007), led to somatic embryos formation from protoplast-derived tissues of $G$. decumbens. The highest number of embryos per agarose bead (2.5) was obtained from tissues cultured previously on CPM3 medium. Fewer somatic embryos (1.0 and 0.17) were regenerated from calli formed on CPM4 and CPM2 media, respectively. Somatic embryogenesis was also induced on other PRM media, but with lower efficiency. A repetitive embryogenic response of callus cells was observed on PRM2 medium after proliferation on CPM4 medium, with just over two embryos produced per agarose bead. On PRM4 medium, which

Table 3. Effect of protoplast culture medium (PCM) and callus proliferation medium (CPM) on the formation of callus from $G$. decumbens protoplasts after $4 \mathrm{wk}$ of culture

\begin{tabular}{lll}
\hline $\begin{array}{l}\text { Protoplast culture } \\
\text { medium }\end{array}$ & $\begin{array}{l}\text { Callus proliferation } \\
\text { medium }\end{array}$ & $\begin{array}{l}\text { Degree of callus } \\
\text { formation }^{\mathrm{a}}\end{array}$ \\
\hline PCM1 & CPM1 & +++ \\
& CPM2 & +++ \\
& CPM3 & +++ \\
CPM4 & +++ \\
PCM2 & CPM1 & + \\
& CPM2 & + \\
& CPM3 & + \\
& CPM4 & ++ \\
\hline
\end{tabular}

\footnotetext{
${ }^{\text {a }}$ Degree of callus formation is expressed as follows: + very small callus covering not more than a quarter of the agarose bead surface, ++ small callus covering not more than a half of the agarose bead surface, +++ callus not exceeding the surface of the agarose bead, and ++++ callus exceeding the surface of the agarose bead
}

Table 4. Number of somatic embryos per agarose bead $(100 \mu l)$ regenerated after 8 wk on different plant regeneration media (PRM)

\begin{tabular}{lllll}
\hline $\begin{array}{l}\text { Callus } \\
\text { proliferation } \\
\text { medium }\end{array}$ & \multicolumn{4}{l}{ Plant regeneration medium } \\
\cline { 2 - 5 } & PRM1 & PRM2 & PRM3 & PRM4 \\
\hline $\mathrm{CPM} 1$ & $0 \mathrm{~b}$ & $0.50 \pm 0.50 \mathrm{ab}$ & $0 \mathrm{~b}$ & $0 \mathrm{~b}$ \\
$\mathrm{CPM} 2$ & $0 \mathrm{~b}$ & $0 \mathrm{~b}$ & $0.17 \pm 0.29 \mathrm{ab}$ & $0 \mathrm{~b}$ \\
$\mathrm{CPM} 3$ & $0 \mathrm{~b}$ & $0 \mathrm{~b}$ & $2.50 \pm 2.29 \mathrm{a}$ & $0 \mathrm{~b}$ \\
$\mathrm{CPM} 4$ & $0 \mathrm{~b}$ & $2.17 \pm 1.04 \mathrm{ab}$ & $1.00 \pm 1.00 \mathrm{ab}$ & $1.17 \pm 1.26 \mathrm{ab}$
\end{tabular}

Values followed by the same letter are not significantly different at $P<0.05$ (HSD test)

facilitated somatic embryogenesis in protoplast cultures of G. crassicaulis (Meng et al. 1996), embryos were produced only from callus formed on CPM4 medium. It is noteworthy that sequential culture on PRM4 followed by PRM3, or on PRM3 followed by PRM4 and again on PRM3, increased the number of plants finally obtained over those obtained on PRM4 or PRM3, respectively (Fig. 2). Out of over 50 regenerants in total, $97.4 \%$ were obtained with the use of PRM3 medium alone or in combination with another medium. The highest percentage of plants $(47.8 \%)$ came from tissues cultured sequentially on PRM3, PRM4, and PRM3 media.

Most of the mature somatic embryos (Fig. 1h) easily converted into plantlets on half-strength MS medium with $2 \%(w / v)$ sucrose. Regenerated plants (Fig. 1i) grew vigorously on full-strength MS medium. Apart from leaf blades (Fig. $1 j$ ) that were wider than those of parent plants (Fig. $1 k$ ), regenerants showed no visible morphological differences under in vitro conditions.

Nuclear DNA Content, Number of Chromosomes, and Stomatal Characteristics. Cytological and cytogenetic analysis of regenerated plants is an indispensable element of research on protoplast culture systems, since the conditions of protoplast isolation and culture, as well as indirect plant regeneration through callus, can induce somaclonal variation, which is often manifested as changed ploidy (Nassour et al. 2003; Sheng et al. 2011). Indeed, within

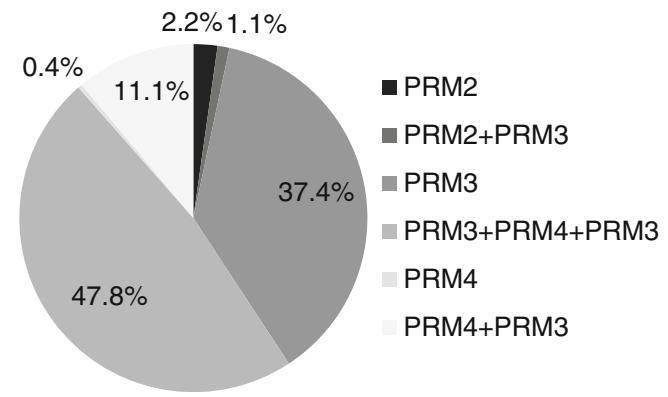

Figure 2. Percentages of $G$. decumbens plants regenerated on specific PRM media and media combinations. 
Figure 3. DNA histograms of nuclei isolated simultaneously from leaves of Pisum sativum (internal standard) and Gentiana decumbens. (a) Seed-derived control plant. (b) protoplastderived regenerant.

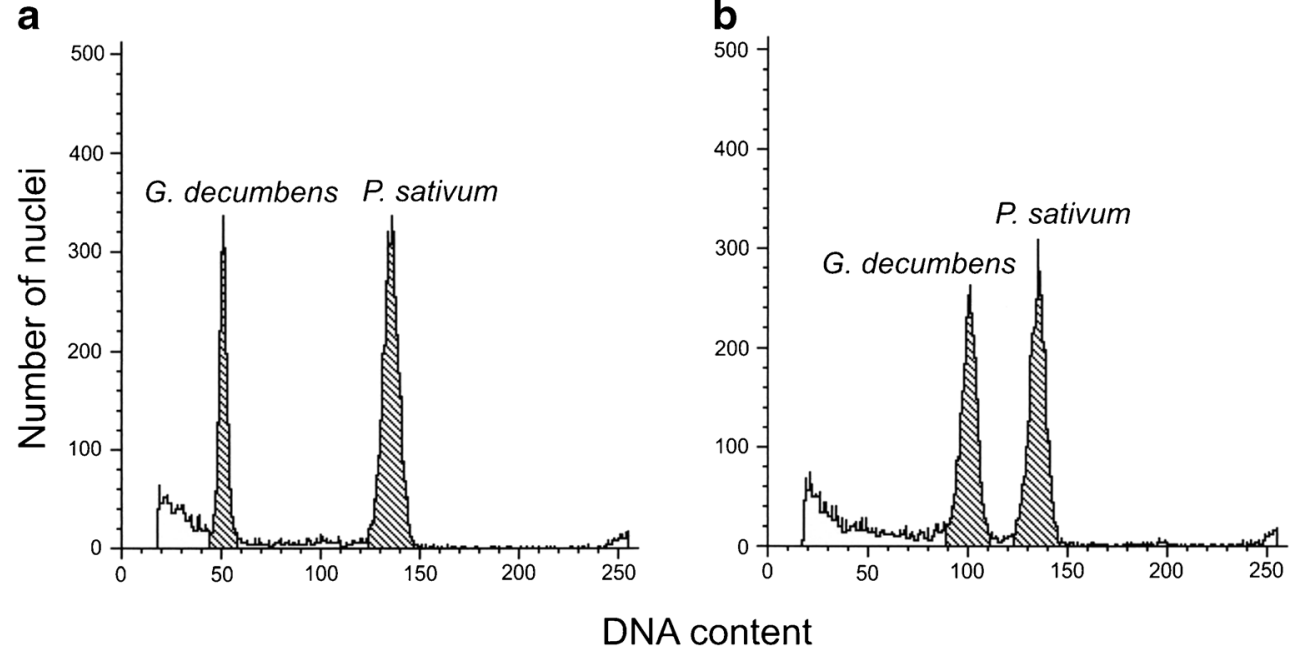

the family Gentianaceae, tetraploid plants were regenerated from protoplasts of shoot tips of E. grandiflorum (Lindsay et al. 1994), and tetraploids and hexaploids were regenerated from cell suspension-derived protoplasts of G. kurroo (Fiuk and Rybczyński 2007).

Flow cytometry is a fast and accurate method of estimating of nuclear DNA content, widely used for analysis of plant material cultured in vitro (Ochatt et al. 2000; Nassour et al. 2003; Thiem and Sliwinska 2003; Elmaghrabi and Ochatt 2006; Konieczny et al. 2012). Its use for the evaluation of $G$. decumbens tissue cultures revealed that the diploid, seed-derived in vitro-grown plants had 3.49 pg/2C DNA (Fig. $3 a$ and Table 5). A similar genome size $(3.63 \mathrm{pg} / 2 \mathrm{C})$ for in vivo-grown plants of this species was reported by Mishiba et al. (2009). However, all 21 protoplast-derived regenerants tested had approximately twofold the DNA content of the seed-derived plants (Fig. 3b) and thus were tetraploid. The results of flow cytometry were confirmed by chromosome counting. In root-tip cells of plants regenerated from protoplasts, 52 chromosomes were present (Fig. 4b), which was twice the number in root-tip cells of control plants (Fig. $4 a$ and Table 5).

Chromosome doubling in plants often results in various morphological and anatomical changes (Dhooghe et al. 2011). Tetraploid Eustoma plants had a range of physical features such as increased width and length of the leaves and bigger flowers (Lindsay et al. 1994). Tetraploid plants of $G$. triflora were also easily distinguishable from diploids by their increased leaf thickness (Morgan et al. 2003). As seed-and protoplast-derived plants of $G$. decumbens showed no conspicuous morphological differences in vitro, except in leaf width, additional indirect markers of polyploidy were tested in order to check their use in distinguishing tetraploid plants from diploids. Measurements of stomata and counting of chloroplasts are easy to perform and less laborious than chromosome counting (Sari et al. 1999). Moreover, in contrast to flow cytometry, their application does not require expensive equipment. The present study showed that stomatal characteristics could be used to evaluate ploidy in $G$. decumbens, since plants regenerated from protoplasts (4x) possessed stomata on their abaxial leaf surfaces that were significantly larger than stomata of parent plants $(2 x)$ growing under the same conditions (Fig. $4 c, d$ and Table 5). The density of the stomata in regenerated tetraploid plants was about half that in control plants (Table 5).

It is unclear why $100 \%$ regenerated plants of $G$. decumbens were autotetraploid. The fully expanded, young gentian leaves used as a protoplast source contained almost exclusively nuclei with a $2 \mathrm{C}$ DNA content (Fig. 3a), so it is not likely that the donor tissue itself was the source of tetraploid cells, unless all of the $2 \mathrm{C}$

Table 5. Cytological characteristics of G. decumbens seed-derived plants (control) and plants regenerated from leaf mesophyll protoplasts

\begin{tabular}{llllll}
\hline Plant type & $\begin{array}{l}\text { 2C DNA content } \\
(\mathrm{pg})\end{array}$ & $\begin{array}{l}\text { Number of } \\
\text { chromosomes }\end{array}$ & $\begin{array}{l}\text { Stomata length } \\
(\mu \mathrm{m})\end{array}$ & $\begin{array}{l}\text { Stomata width } \\
(\mu \mathrm{m})\end{array}$ & $\begin{array}{l}\text { Number of stomata per square millimeter } \\
\text { of leaf blade area }\end{array}$ \\
\hline Control & $3.49 \pm 0.07 \mathrm{~b}$ & 26 & $35.99 \pm 3.05 \mathrm{~b}$ & $33.84 \pm 6.26 \mathrm{~b}$ & $\begin{array}{l}189.73 \pm 44.98 \mathrm{a} \\
\text { Regenerant }\end{array}$ \\
\hline
\end{tabular}

Values in the same column followed by the same letter are not significantly different at $P<0.05$ (HSD test) 
Figure 4. Chromosome counting and stomatal characteristics of $G$. decumbens. $(a, b)$ Mitotic metaphase chromosomes in root-tip cells of a seed-derived parent plant $(a)$ and a protoplast-derived regenerant (b). $(c, d)$ Stomata of a seedderived parent plant $(c)$ and a tetraploid protoplast-derived regenerant $(d)$.
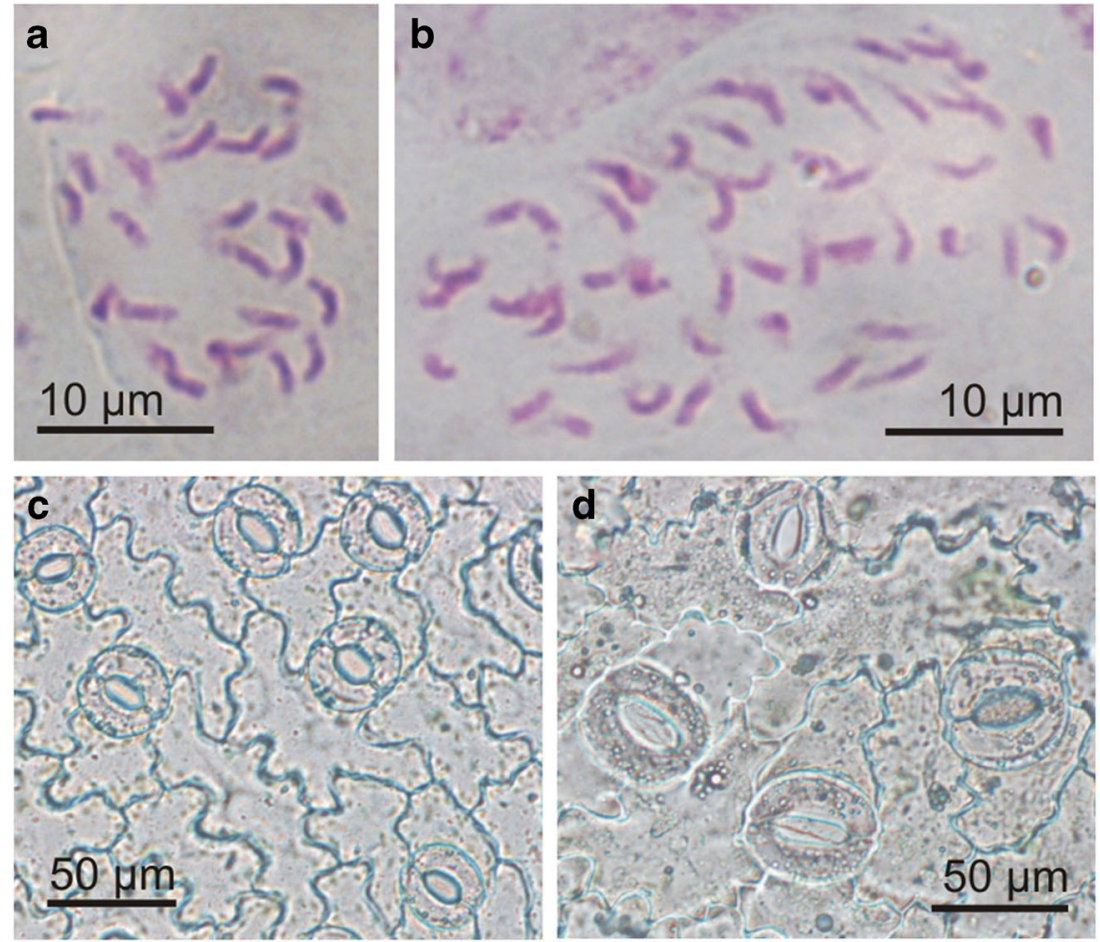

cells left the cell cycle and were arrested at the $\mathrm{G}_{0}$ state. Bergounioux et al. (1988), studying the ability of protoplasts that originated from cells at different phases of the cell cycle to undergo cell division, concluded that the differentiated $\mathrm{G}_{0}$ state is not conducive to division. However, in the tissue they used as a source of protoplasts, $4 \mathrm{C}$ cells (being at the $\mathrm{G}_{2}$ phase of the cell cycle) occurred at a higher frequency than in the leaves of $G$. decumbens. Another reason for regeneration of polyploid plants can be spontaneous fusions during protoplast isolation, which occur especially when protoplasts are prepared from actively dividing cultured cells (Bhojwani and Razdan 1996). However, exposing the donor cells to a strong plasmolyticum before enzyme treatment, as in this study, should sever the plasmodesmatal connection and, consequently, reduce the frequency of spontaneous fusion. Thus, it is more likely that divisions of protoplastderived cells were disturbed. As reported previously, protoplast cultures are especially unstable because of a high frequency of errors in microtubule synthesis, spindle formation and orientation, and chromatid segregation (Karp 1994). Moreover, as reported for Nicotiana plumbaginifolia Viv. and Brassica napus L., protoplast-derived cells with a 4C nuclear DNA content can divide faster that those with a $2 \mathrm{C}$ DNA content (Magnien et al. 1982; Chen et al. 1994).

Yet another possibility is that polyploidization occurred during callus formation. As shown for P. sativum (Ochatt et al. 2000) and Medicago truncatula Gaertn. (Elmaghrabi and Ochatt 2006), callus cells often undergo endoreduplication (amplification of DNA without mitosis), which causes an increase in the frequency of cells with a DNA content higher than $2 \mathrm{C}$. The combination of plant growth regulators added to the culture media could promote a certain pathway of DNA amplification (endoreduplication or cell division; Lukaszewska et al. 2012). Verification of the regeneration mechanism of tetraploid $G$. decumbens plants will require further cytogenetic studies. Nevertheless, the results presented here support the suggestion that cells with higher ploidy can reenter the cell cycle more easily than cells with 2C DNA content in in vitro culture (Magnien et al. 1982; Chen et al. 1994).

Although somaclonal variation is undesirable for micropropagation or ex situ conservation of plant diversity (Takagi et al. 2011), it can provide a useful means of plant genetic improvement (Karp 1994). Polyploidy can lead directly to morphological, anatomical, and physiological changes, which may be exploited in plant breeding for the production of cultivars with increased ornamental value or higher capacity to cope with different stresses (Dhooghe et al. 2011). For medicinal species, polyploids often exhibit enhanced production and/or qualitative improvement in the biochemical profile of active compounds (Dhawan and Lavania 1996). Thus, further assessment of the morphological traits of autotetraploid $G$. decumbens plants for their horticultural potential, as well as for analysis of secondary metabolites, is worthwhile. 
Acknowledgments The authors wish to thank Aleksandra Chomacka for her technical assistance in flow cytometry analysis and Dr. Michael R. Davey (University of Nottingham, UK) for critical comments on the manuscript. This work was supported by the Polish Ministry of Science and Higher Education (Grant No. 3P04C 037 23).

Open Access This article is distributed under the terms of the Creative Commons Attribution License which permits any use, distribution, and reproduction in any medium, provided the original author(s) and the source are credited.

\section{References}

Bergounioux C, Perennes C, Brown SC, Sarda C, Gadal P (1988) Relation between protoplast division, cell-cycle stage and nuclear chromatin structure. Protoplasma 142:127-136

Bhojwani SS, Razdan MK (1996) Plant tissue culture: theory and practice, a revised edition. Studies in plant science 5. Elsevier Science BV, Amsterdam

Cai Y, Liu Y, Liu Z, Zhang F, Fe X, Xia G (2009) High-frequency embryogenesis and regeneration of plants with high content of gentiopicroside from the Chinese medicinal plant Gentiana straminea Maxim. In Vitro Cell Dev Biol Plant 45:730-739

Chen Z, Hsiao K-C, Bornman CH (1994) Ploidy and division efficiency of petiolar protoplasts of Brassica napus. Hereditas 120:41-46

Davey MR, Anthony P, Power JB, Lowe KC (2005) Plant protoplasts: status and biotechnological perspectives. Biotechnol Adv 23:131171

Dhawan OP, Lavania UC (1996) Enhancing the productivity of secondary metabolites via induced polyploidy: a review. Euphytica 87:8189

Dhooghe E, Van Laere K, Eeckhaut T, Leus L, Van Huylenbroeck J (2011) Mitotic chromosome doubling of plant tissues in vitro. Plant Cell Tissue Organ Cult 104:359-373

Dungerdorj D, Tsetsegmaa S, Purevsuren S, Bayasgalan B (2006) On the phytochemical investigation of the genus Gentiana used for the treatment of liver diseases in Mongolian Traditional Medicine. Postępy Fitoterapii 2:71-74

Elmaghrabi A, Ochatt S (2006) Isoenzymes and flow cytometry for the assessment of true-to-typeness of calluses and cell suspensions of barrel medic prior to regeneration. Plant Cell Tissue Organ Cult 85: $31-43$

Fiuk A, Rybczyński JJ (2007) The effect of several factors on somatic embryogenesis and plant regeneration in protoplast cultures of Gentiana kurroo (Royle). Plant Cell Tissue Organ Cult 91:263-271

Fiuk A, Rybczyński JJ (2008a) Factors influencing efficiency of somatic embryogenesis of Gentiana kurroo (Royle) cell suspension. Plant Biotechnol Rep 2:33-39

Fiuk A, Rybczyński JJ (2008b) Genotype and plant growth regulatordependent response of somatic embryogenesis from Gentiana spp. leaf explants. In Vitro Cell Dev Biol Plant 44:90-99

Frearson EM, Power JB, Cocking EC (1973) The isolation, culture and regeneration of Petunia leaf protoplasts. Dev Biol 33:130-137

Ho TN, Liu SW (1990) The infrageneric classification of Gentiana (Gentianaceae). Bull Br Mus Nat Hist (Bot) 20:169-192

Ho TN, Pringle JS (1995) Gentianaceae. Flora China 16:1-139

Hosokawa K, Nakano M, Oikawa Y, Yamamura S (1996) Adventitious shoot regeneration from leaf, stem and root explants of commercial cultivars of Gentiana. Plant Cell Rep 15:578-581

Jomori H, Takahata Y, Kaizuma N (1995) Plant regeneration from leafderived calli of gentians and their protoplast culture. Acta Horticult 392:81-86
Karp A (1994) Origins, causes and uses of variation in plant tissue cultures. In: Vasil IK, Thorpe TA (eds) Plant cell and tissue culture. Kluwer Academic Publishers, Dordrecht, pp 139-152

Kletter C, Glasl S, Thalhammer T, Narantuya S (2008) Traditional Mongolian Medicine - a potential for drug discovery. Sci Pharm 76:49-63

Köhlein F (1991) Gentians. Timber Press, Portland

Konieczny R, Sliwinska E, Pilarska M, Tuleja M (2012) Morphohistological and flow cytometric analyses of somatic embryogenesis in Trifolium nigrescens Viv. Plant Cell Tissue Organ Cult 109:131-141

Kunitake H, Nakashima T, Mori K, Tanaka M, Mii M (1995) Plant regeneration from mesophyll protoplasts of lisianthus (Eustoma grandiflorum) by adding activated charcoal into protoplast culture medium. Plant Cell Tissue Organ Cult 43:59-65

Larkin PJ (1976) Purification and viability determinations of plant protoplasts. Planta 128:213-216

Lindsay GC, Hopping ME, O'Brien IEW (1994) Detection of protoplastderived DNA tetraploid Lisianthus (Eustoma grandiflorum) by leaf and flower characteristics and by flow cytometry. Plant Cell Tissue Organ Cult 38:53-55

Lukaszewska E, Virden R, Sliwinska E (2012) Hormonal control of endoreduplication in sugar beet (Beta vulgaris $\mathrm{L}$.) seedlings growing in vitro. Plant Biol 14:216-222

Magnien E, Dalschaert X, Faraoni-Sciamanna P (1982) Transmission of a cytological heterogeneity from the leaf to the protoplasts in culture. Plant Sci Lett 25:291-303

Meng Y, Gao Y, Jia J (1996) Plant regeneration from protoplasts isolated from callus of Gentiana crassicaulis. Plant Cell Rep 16:88-91

Mikuła A, Rybczyński JJ (2001) Somatic embryogenesis of Gentiana genus I. The effect of the preculture treatment and primary explant origin on somatic embryogenesis of Gentiana cruciata (L.), G. pannonica (Scop.), and G. tibetica (King). Acta Physiol Plant 23:15-25

Mikuła A, Skierski J, Rybczyński JJ (2002) Somatic embryogenesis of Gentiana genus III. Characterization of three-year-old embryogenic suspensions of $G$. pannonica originated from various seedling explants. Acta Physiol Plant 24:311-322

Mishiba K, Yamane K, Nakatsuka T, Nakano Y, Yamamura S, Abe J, Kawamura H, Takahata Y, Nishihara M (2009) Genetic relationships in the genus Gentiana based on chloroplast DNA sequence data and nuclear DNA content. Breed Sci 59:119-127

Momčilović I, Grubišić D, Nešković M (1997) Micropropagation of four Gentiana species ( $G$. lutea, G. cruciata, G. purpurea and G. acaulis). Plant Cell Tissue Organ Cult 49:141-144

Morgan ER, Hofmann BL, Grant JE (2003) Production of tetraploid Gentiana triflora var. japonica 'Royal Blue' plants. N Z J Crop Hortic Sci 31:65-68

Murashige T, Skoog F (1962) A revised medium for rapid growth and bioassays with tobacco tissue cultures. Physiol Plant 15:473-497

Myagmar BE, Aniya Y (2000) Free radical scavenging action of medicinal herbs from Mongolia. Phytomedicine 7:221-229

Nakano M, Hosokawa K, Oomiya T, Yamamura S (1995) Plant regeneration from protoplasts of Gentiana by embedding protoplasts in gellan gum. Plant Cell Tissue Organ Cult 41:221-227

Nassour M, Chassériaux G, Dorion N (2003) Optimization of protoplastto-plant system for Pelargonium $\times$ hortorum 'Alain' and genetic stability of the regenerated plants. Plant Sci 165:121-128

Nishihara M, Nakatsuka T, Hosokawa K, Yokoi T, Abe Y, Mishiba K, Yamamura S (2003) Dominant inheritance of white-flowered and herbicide-resistant traits in transgenic gentian plants. Plant Biotechnol 23:25-31

O'Brien IEW, Lindsay GC (1993) Protoplasts to plants of Gentianaceae. Regeneration of lisianthus (Eustoma grandiflorum) is affected by calcium ion preconditioning, osmolarity and $\mathrm{pH}$ of the culture media. Plant Cell Tissue Organ Cult 33:31-37 
Ochatt SJ, Mousset-Déclas C, Rancillac M (2000) Fertile pea plants regenerate from protoplasts when calluses have not undergone endoreduplication. Plant Sci 156:177-183

Qureshi RA, Gilani SA, Ashraf M (2007) Ethnobotanical studies with special reference to plant phenology at Sudhan Gali and Ganga Chotti Hills (District Bagh, A.K.). EJEAFChe 6:2207-2215

Rybczyński JJ, Davey M, Tomiczak K, Fiuk A, Mikuła A (2015) Systems of plant regeneration in gentian in vitro cultures. In: Rybczyński JJ, Davey M, Mikuła A (eds). The Gentianaceae. Biotechnology and application vol. 2. Springer (in press)

Sari N, Abak K, Pitrat M (1999) Comparison of ploidy level screening methods in watermelon: Citrullus lanatus (Thunb.) Matsum. and Nakai. Sci Hortic 82:265-277

Sheng X, Zhao Z, Yu H, Wang J, Xiaohui Z, Gu H (2011) Protoplast isolation and plant regeneration of different doubled haploid lines of cauliflower (Brassica oleracea var. botrytis). Plant Cell Tissue Organ Cult 107:513-520
Sliwinska E, Zielinska E, Jedrzejczyk I (2005) Are seeds suitable for flow cytometric estimation of plant genome? Cytometry 64A:72-79

Takagi H, Sugawara S, Saito T, Tasaki H, Yuanxue L, Kaiyun G, Han DS, Godo T, Nakano M (2011) Plant regeneration via direct and indirect adventitious shoot formation and chromosome doubled somaclonal variation in Titanotrichum oldhamii (Hemsl.) Solereder. Plant Biotechnol Rep 5:187-195

Takahata Y, Jomori H (1989) Plant regeneration from mesophyll protoplasts of Gentiana (Gentiana scabra Bungei). Plant Tissue Cult Lett 6:19-21

Takahata Y, Jomori H, Miyano S, Kunitake H, Mii M (1995) Regeneration of plants from protoplasts of Gentiana species (Gentian). In: Bajaj YPS (ed) Biotechnology in agriculture and forestry, vol. 34. Plant protoplasts and genetic engineering VI. Springer, Berlin, pp 57-62

Thiem B, Sliwinska E (2003) Flow cytometry analysis of nuclear DNA content in cloudberry (Rubus chamaemorus L.) in vitro cultures. Plant Sci 164:129-134 